\title{
First measurements of the methane concentration in the North Sea with a new in-situ device
}

\author{
G. WERNECKE, G. FLÖSER, S. KORN, C. WEITKAMP \& W. MICHAELIS
}

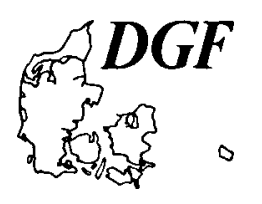

\begin{abstract}
Wernecke, G., Flöser, G., Korn, S., Weitkamp, C. \& Michaelis, W.: First measurements of the methane concentration in the North Sea with a new in-situ device. Bulletin of the Geological Society of Denmark, Vol. 41, pp. 5-11. Copenhagen, 1994-03-30.

https://döi.örg/10.37570/bgsd-1995-41-01
\end{abstract}

\begin{abstract}
A device is briefly described for the continuous in-situ measurement of methane gas dissolved in sea water. The device extracts dissolved gas from a continuous flow of water and quantitatively determines the methane partial pressure in the gas phase by laser absorption spectrometry. A lower detection limit of $30 \mathrm{ppt}$ (parts per trillion, $30 \mathrm{pg}$ of methane per $\mathrm{g}$ of water) is achieved, and the dynamic range exceeds six orders of magnitude. Thus, the natural background concentra-tion of the open ocean (35 ppt) can be measured. First measurements with the device have been taken in the North Sea. Depth profiles at Statpipe, in the Bømla Fjord and at the location of a seepage in the Gullfaks area are shown. Horizontal profiles across a natural seepage show the distribution of the methane around the source. Measurements at a gas injection wellhead may give a hint of a microleakage of the structure.
\end{abstract}

G. Wernecke, G. Flöser, S. Korn, C. Weitkamp \& W. Michaelis, GKSS Forschungszentrum Geesthacht GmbH, Postfach 1160, D-21494 Geesthacht, Germany, October 20th, 1992.

\section{Introduction}

Next to water vapor methane is one of the most important greenhouse gases. The methane cycle of the biosphere has been the subject of many investigations, and its features are now well understood (Heyer, 1990). As to the marine environment, however, open questions persist, especially in estimating methane fluxes from the oceans into the atmosphere. As to practical applications, methane concentration measurements can be useful for the exploration of new gas and oil fields. Also for the inspection of offshore structures like pipelines or wellheads the detection of increased methane concentrations may be valuable.

To the authors' best knowledge no sufficiently sensitive method is at present available for the direct analysis of methane in the water phase. The usual analytical procedure of methane concentration measurements in the water column consists in collecting water samples, taking them on board a ship, and carrying out the analysis later in a laboratory after purge-and-trap or ultrasonic degassing (Swinnerton \& Linnenbom 1967; Schmitt, Faber, Botz \& Stoffers 1991). Hoisting up the samples consumes time and results in a poor spatial resolution. It is hardly possible to take horizontal or vertical profiles with this technique. Also it is quite uncertain whether samples reaching the surface are intact, i.e. without loss of dissolved gas, especially from greater depths. MEDUSA eliminates these problems by measuring methane and oxygen concentrations in-situ and continuously. In this paper only methane concentrations will be discussed. The acronym MEDUSA stands for MEthane Detection for UnderSea Applications.

Methane concentrations in the sea range from 5 ppt $(5$ pg of methane per $\mathrm{g}$ of water equivalent to $3.5 \mathrm{nl} / \mathrm{l}$ or 0.31 nmol/l) background concentration of the open ocean in depths of $5000 \mathrm{~m}$ (Lamontagne, Swinnerton, Linnenbom \& Smith 1973; Brooks \& Sackett 1973; Charlou, Rona \& Bougault 1987, measured by purge-and-trap methods) up to an upper limit given by thermodynamic equilibrium between pure methane bubbles and the water phase. Assuming a maximum operational depth of $300 \mathrm{~m}$ for the North Sea this maximum is approximately $660 \mathrm{ppm}$.

The present paper briefly describes the essential features of MEDUSA and gives a short account of its first measurements.

\section{Measurement system}

Fig. 1 shows the principle of operation. Water is sucked into a membrane desorption cell where a flow of stripping gas takes up the gases which have diffused through the membrane. The gas mixture is then fed into an analysis cell; its methane content is determined by laser absorptiometry.

The desorption cell consists of a membrane module made from microporous hollow polypropylene fibres. 


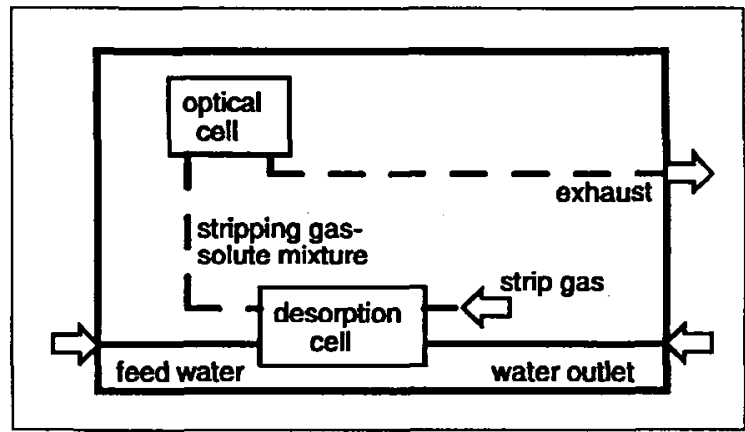

Fig. 1. MEDUSA principle of operation

Because the material is hydrophobic and the diameter of the pores in the fibre walls is less than $1 \mu \mathrm{m}$ the water is kept inside of the fibre by the surface tension. The solved volatile gases can diffuse through the pores into the gas phase (fig. 2). A module made from 18000 fibres with a length of $0.1 \mathrm{~m}$ and a diameter of $280 \mu \mathrm{m}$ has a volume of $0.510^{-3} \mathrm{~m}^{3}$ (0.5 liter). A desorption efficiency of 60 to $70 \%$ and a time constant $(0-90 \%)$ of $1.2 \mathrm{~min}$ are obtained at a sample flow rate of 6 liters $/ \mathrm{min}$. The desorption process will be described in detail somewhere else.

The analysis is accomplished in the gas phase by absorption of laser radiation (fig. 3). Methane absorbs strongly at the $3.39 \mu \mathrm{m}$ emission wavelength of the $\mathrm{HeNe}$ laser. The methane partial pressure in the gas phase is determined from the attenuation of the laser intensity by the gas in the absorption cell. Taking into account the mass balance in the desorption cell then yields the methane concentration in the feed water. The total system is housed in a pressure vessel designed for a maximum depth of $300 \mathrm{~m}$. Presently the prototype does not provide for steering or navigation. For applications with stringent needs for precise positioning, the system needs some kind of remotely operated vehicle as a carrier. The functions of MEDUSA are entirely controlled by computers from the mothership, a cable connection to the ship for data and energy transfer is necessary. Table 1 shows the specifications. The measurement system is described in more

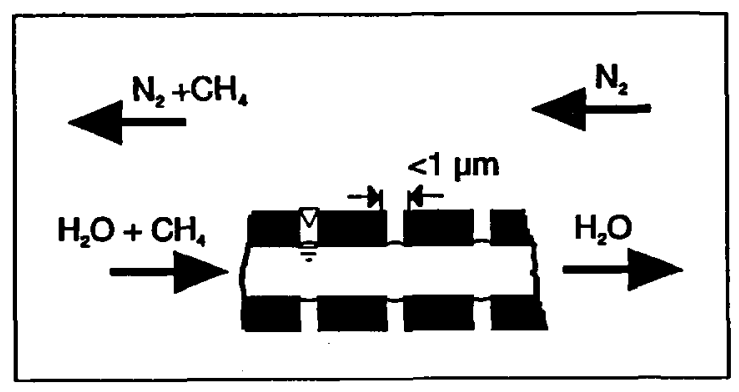

Fig. 2. Schematics of hollow microporous polypropylene fibre. The whole module consists of 18000 fibres of $0.1 \mathrm{~m}$ length and 280 um inner diameter.

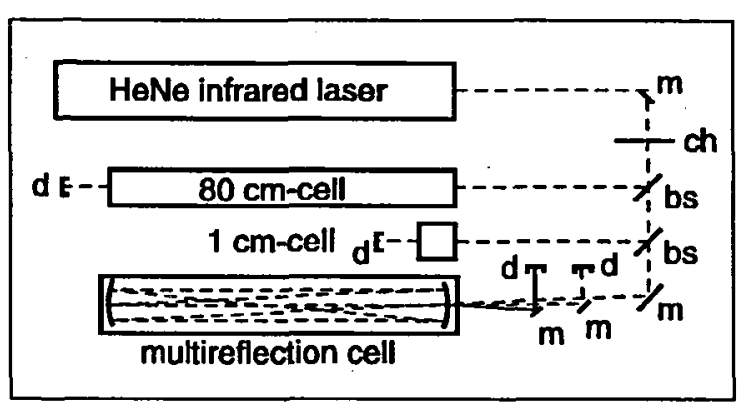

Fig. 3. Optical setup with three absorption cells of different length; d: detector, m: mirror, bs: beam splitter, ch: chopper.

detail in (Wernecke, Flöser, Korn, Weitkamp \& Michaelis, 1991).

Validation measurements with water samples containing from $50 \mathrm{ppt}$ to $30 \mathrm{ppm}$ of methane have been conducted by gas chromatography. A system test at 30 bar external pressure equivalent to $300 \mathrm{~m}$ water depth has been carried out successfully at the GKSS underwater simulation facility.

\section{Measurements in the river Elbe}

For measurements in the river Elbe the system was placed aboard the research ship LUDWIG PRANDTL, and water was pumped through the device. Concentrations of 1-2 ppb were measured in the main stream of the river. In stagnant water, the concentrations were much higher. At the inner end of a harbor basin $20 \mathrm{ppb}$ of methane were measured. Also in a shallow bight on the side of the main river the concentration increases when water from the flat shore that is rich in organic matter passes the bight during low tide, and decreases again when the rising tide brings in fresh water from the main stream. The methane at these locations is believed to originate from biological processes in the sediment, especially in the mud.

\section{Measurements in the North Sea}

For the measurements in the North Sea MEDUSA was connected to the ROV "SOLO" on board M/S "Seaway Commander", operated by Stolt-Comex Seaway A/S, Haugesund, Norway. Fig. 4 shows the locations of the measurements in the North Sea.

\section{Depth profiles}

Fig. 5 shows a depth profile above statpipe at the location $459428 \mathrm{E}, 6782683 \mathrm{~N}$ (coordinates are always given in UTM coordinates zone 31) near Haugesund. The apparatus was first lowered down to $40 \mathrm{~m}$. To reproduce the 
methane concentration range

time constant $(0-90 \%)$

sample water flow rate through the system

maximum operational depth

dimensions

weight

power requirements
$30 \mathrm{pg} / \mathrm{g}$ (ppt) to $100 \mu \mathrm{g} / \mathrm{g}$ (ppm)

appr. 1.2 minutes

6 liters/minute

$300 \mathrm{~m}$

length: $4 \mathrm{~m}$; diameter: $0.8 \mathrm{~m}$

$2600 \mathrm{~kg}$ in air, $0 \mathrm{~kg}$ in water

$4 \mathrm{kVA}, 220$ or $1000 \mathrm{~V}, 50$ or $60 \mathrm{~Hz}$, single phase increase in concentration, MEDUSA was taken up to the surface again. It then dived to the sea bottom. A methane maximum appears at $30 \mathrm{~m}$ depth just below the surface layer. Similar maxima have been measured by Lamontagne et al. 1973, Charlou et al. 1987 or Charlou, Bougault, Appriou, Baptiste, Etoubleau \& Birolleau 1991. Since oxygen is still available methane production by bacteria is very unlikely. The concentration profile of fig. 5 excludes diffusion from the sediment. Although it has been suggested that there is methane production by protozoa and in the intestinal tracts of fish (Heyer, 1990), there is still no satisfactory explanation. Comparison measurements were carried out by taking water samples with a TPN-water sampler (Hydro Bios). The samples were degassed by an ultrasonic method similar to that described by Schmitt et al. 1991 and then analysed by gas chromatography with a flame ionisation detector. There is quite

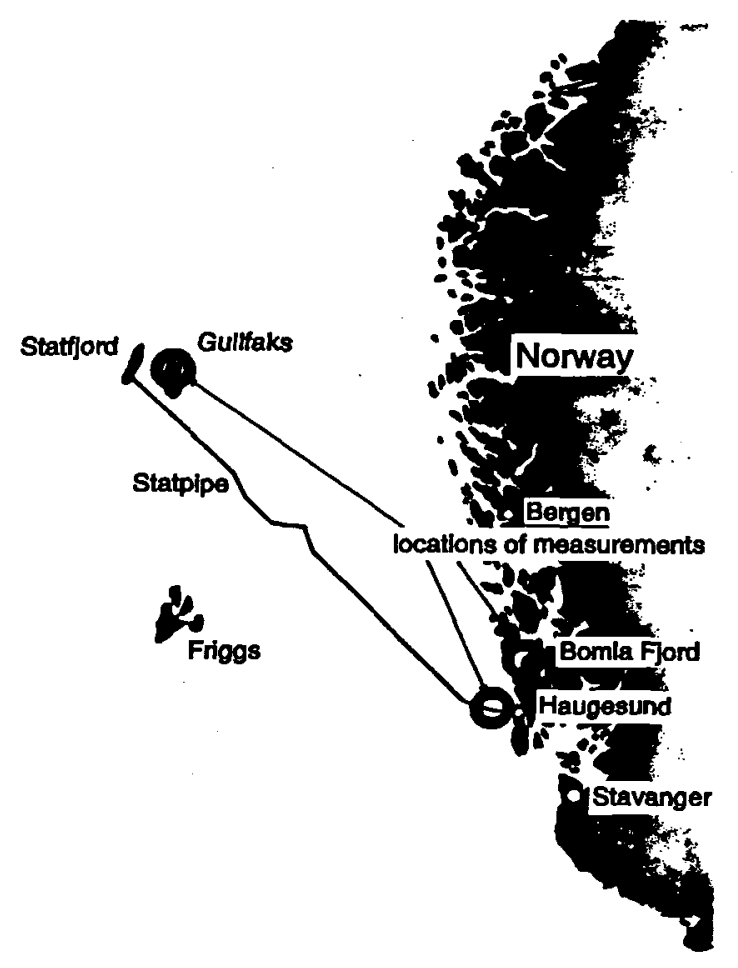

Fig. 4. Geographic area of MEDUSA North Sea test measurements between 31th July and 3rd August 1992. good agreement, considering that it was not possible to get the samples exactly at the same location of the measurement points of MEDUSA, and that loss of gas during sampling, storage, and the subsequent analysis steps cannot be totally excluded.

The depth profile taken in the Bømla fjord (fig. 6) shows no maximum. In addition, concentrations are substantially higher than the values expected for equilibrium between water and the atmosphere (approximately 35 ppt) with a slight decrease close to the surface. At the depth of $135 \mathrm{~m}$ MEDUSA did not move for $25 \mathrm{~min}$ in order to allow taking water samples with a water sampler.

\section{water temperature, ${ }^{\circ} \mathrm{C}$}

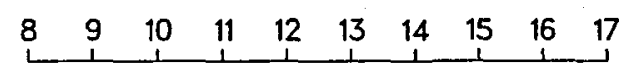

oxygen concentration, $\mathrm{mg} / 1$

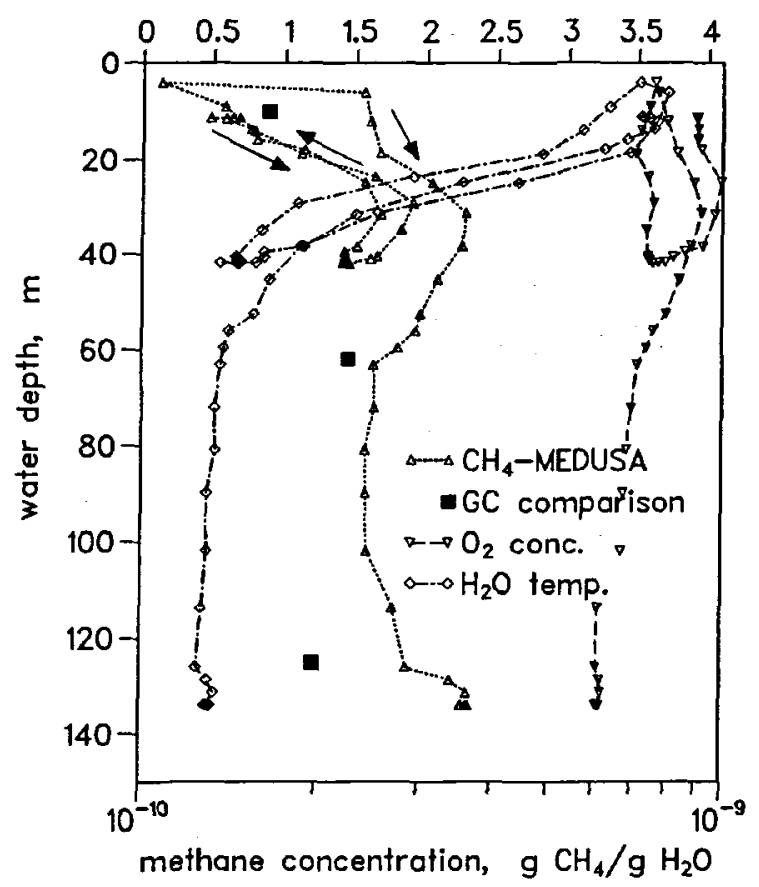

Fig. 5. Results of methane depth measurement with MEDUSA at Statpipe on 1th august 1992. Squares are results of gas chromatographic analysis of three water samples on shipboard. Oxygen and temperature profiles are also plotted. 


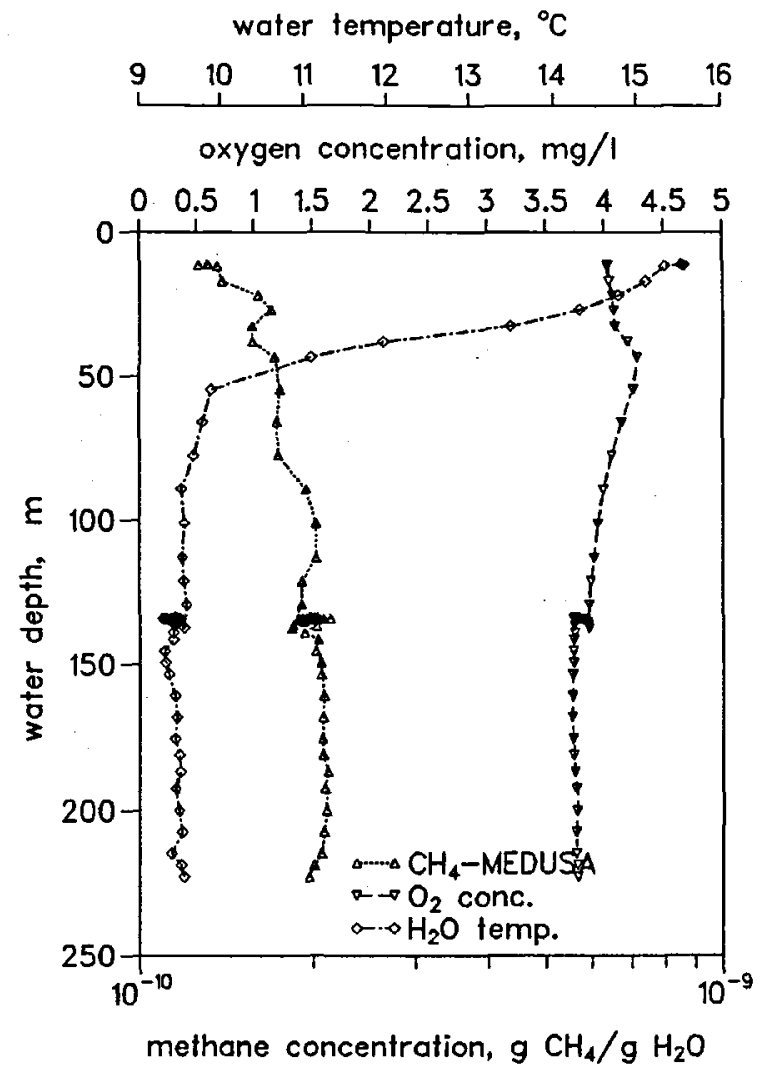

Fig. 6. Result of methane depth profile measurement with MEDUSA at Bømla Fjord on 1th august 1992. Oxygen and temperature profiles are also plotted.

\section{Measurements of a seepage at Gullfaks}

Measurements along horizontal lines at different heights above the sea bottom between $459340 \mathrm{E} 6782450 \mathrm{~N}$ and $459500 \mathrm{E} 6782900 \mathrm{~N}$ (locations in fig. 7) are shown in fig. 8. It can clearly be seen that there is a vertical gradient. The first two passes are made at a speed of about $0.5 \mathrm{~m} / \mathrm{s}$. Because a seepage was assured to be at this location a third pass was carried out at very low speed. At the distance point $250 \mathrm{~m}$ the seepage was found $10 \mathrm{~m}$ off the line ( 459428 E $6782683 \mathrm{~N}$ ), and it could be observed with video cameras. The source looks like a fissure with a length of $5 \mathrm{~m}$ at least. At the locations at $220 \mathrm{~m}$ and 250 $\mathrm{m}$ MEDUSA did not move at all for a period in order to allow multiple measurements. Large variations in concentration were measured obviously caused by plumes flowing around MEDUSA. It is amazing that the concentration remains as low as $1 \mathrm{ppm}$, which is one-hundredth the equilibrium concentration at that depth for pure methane, even when MEDUSA is sitting in the middle of the gas bubbles.

The location of horizontal profiles across the seepage, measured along the direction of the current in different heights above the sea bottom are shown in fig. 9, the

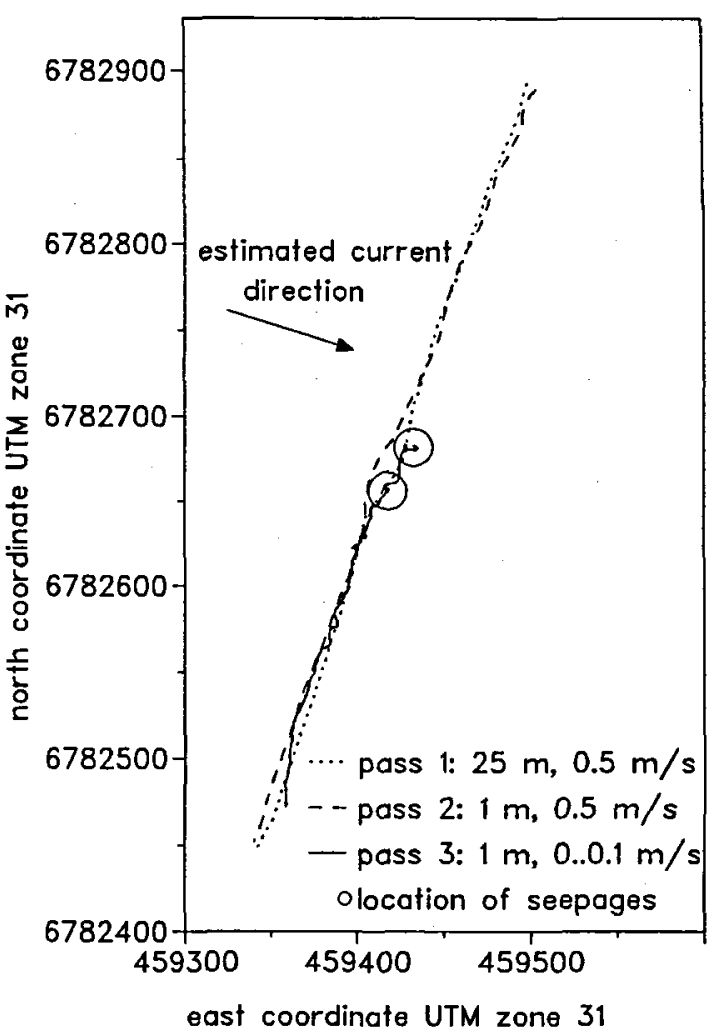

Fig. 7. Track chart of SOLO and MEDUSA along the line Gullfaks between 459340E 6782450N and 459500E 6782900N. Water depth is between $150 \mathrm{~m}$ and $170 \mathrm{~m}$.

results in fig. 11. It can be seen that the high concentration decreases very quickly beyond a distance of about 40 $\mathrm{m}$ from the source. As one can expect the concentration is higher on the downstream side than on the upstream side. The residual concentration at the end of pass 1 is due to the increased time constant when concentration changes larger than four orders of magnitude occur. A further mapping of the concentration profiles around the seepage would have been interesting but because of adverse weather conditions the measurements had to be stopped at this point.

Fig. 10 shows the depth profile just above the seepage with a concentration maximum at $40 \mathrm{~m}$ depth that is just below the surface layer similar to the profile shown in fig. 5. It is either a plume of the seepage, or there is a barrier at this depth for the exchange of methane-enriched water from below with surface water. Further investigations would be interesting.

Fig. 12 shows the ability of MEDUSA to track an elevated methane concentration from its first appearance to the source. At $12 \mathrm{~h}$ MEDUSA had zeroed in on a small seepage that could then also be seen on video ( $460136 \mathrm{E}$ $6783924 \mathrm{~N})$. 
Fig. 8. Horizontal profiles along the line given by fig. 7 at two different heights above seabottom and different speed.

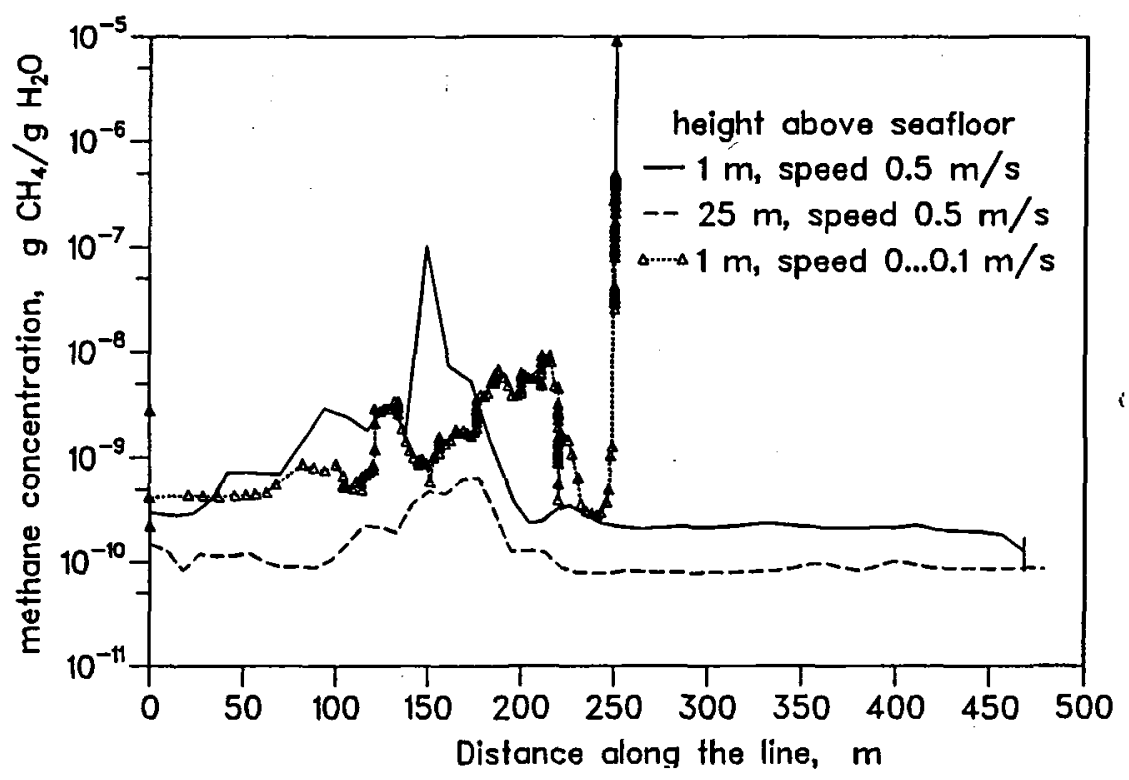

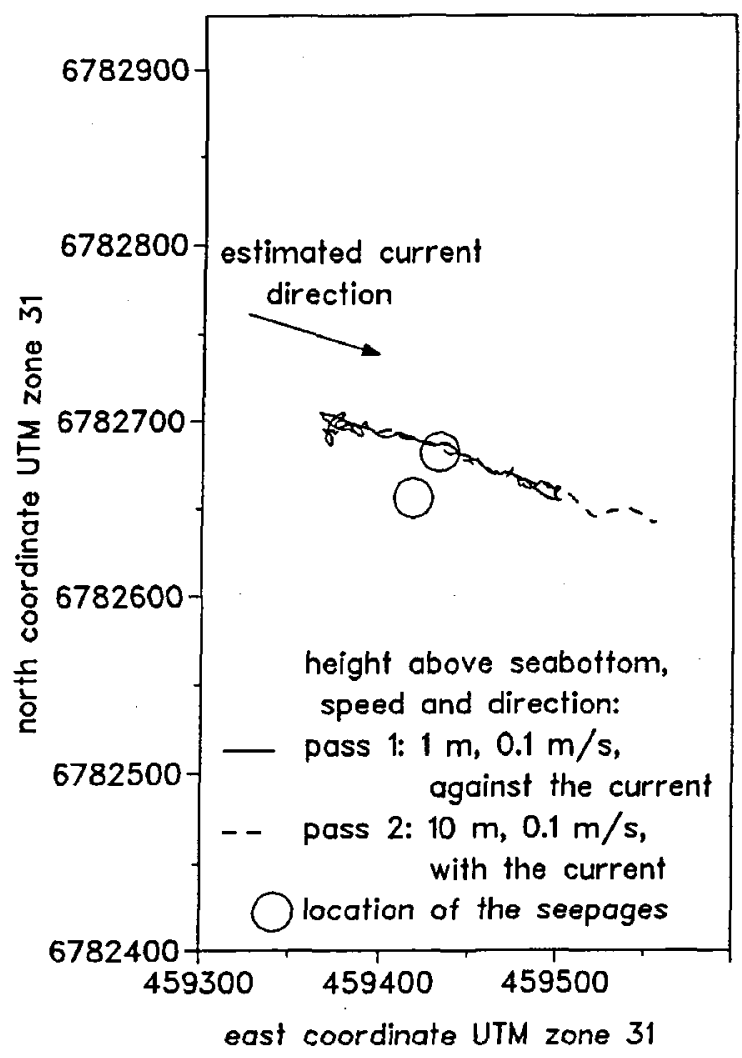

Fig. 9. Track chart of SOLO and MEDUSA across the seepage.

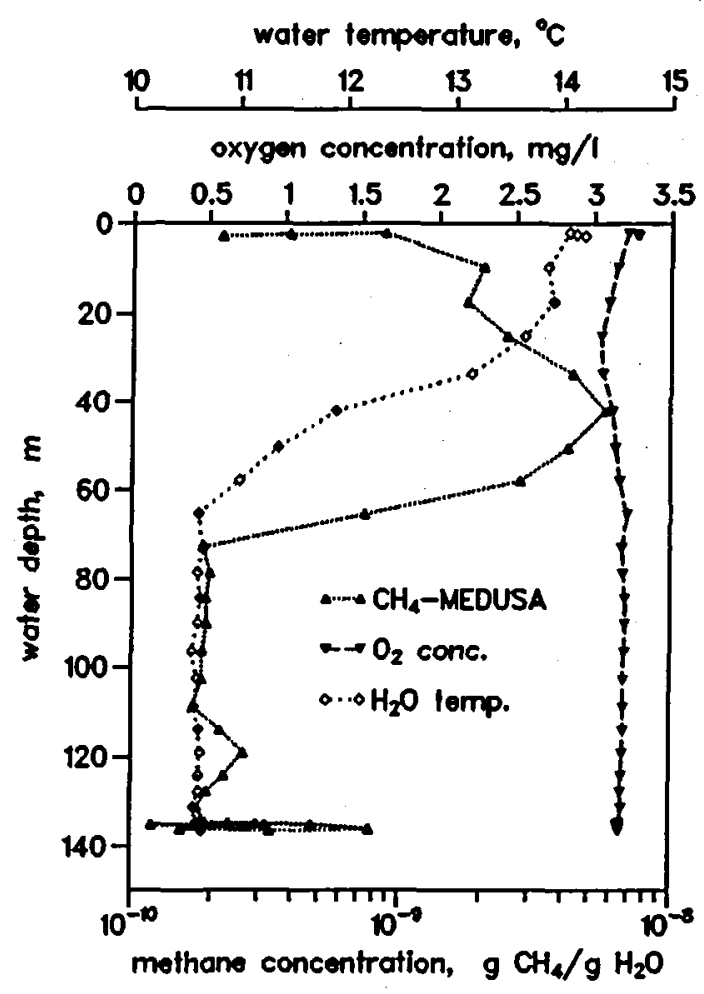

Fig. 10. Result of methane depth profile measurements with MEDUSA at the location of the seepage on 2th august 1992. Oxygen and temperature profiles are also plotted. 


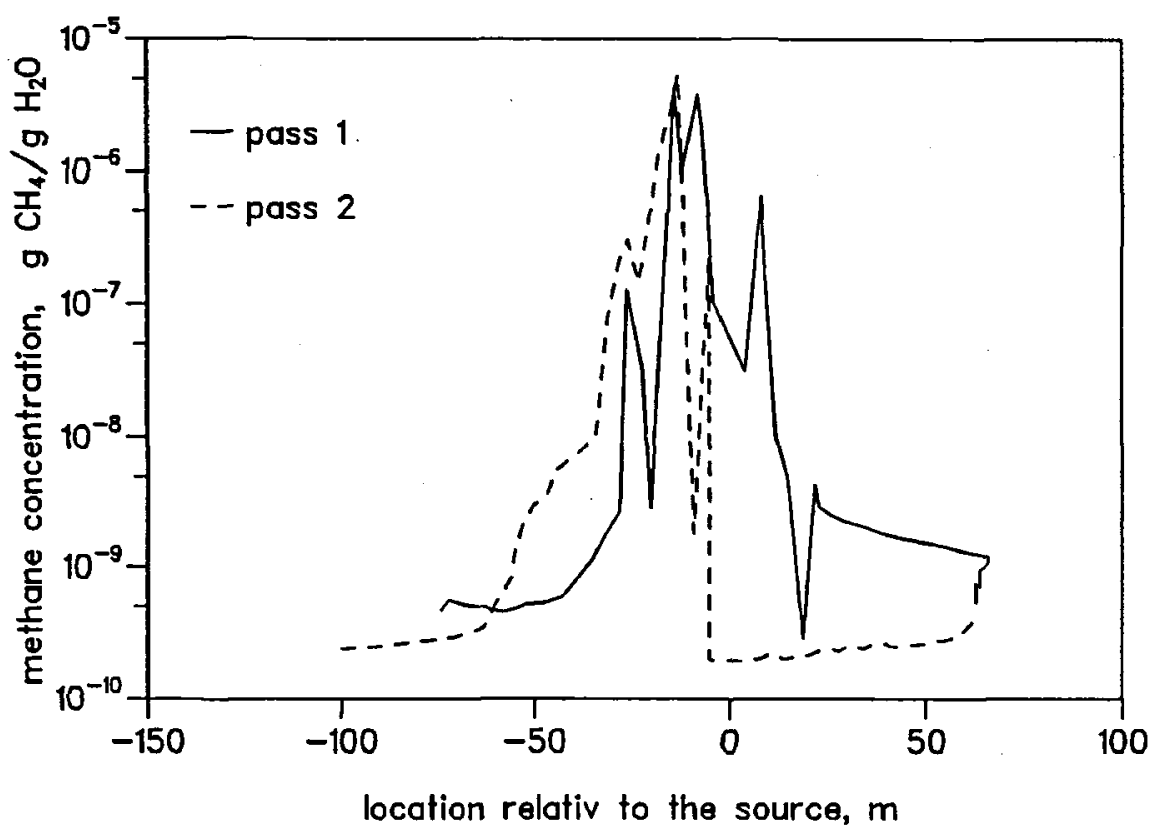

Fig. 11. Horizontal profiles across the seepage on Gullfaks along the tracks given by fig. 9 at two different heights above the seabottom.

Measurements at a gas injection wellhead

With kind permission of the Statoil Company measurements could be carried out at the gas injection wellhead A4H in the Gullfaks oil field. Fig. 13 shows the results. It is obvious that at one location of the structure the concentration is higher than in the surroundings. On the video no leakage could be observed. Whether the concentration increase was caused by a micro leakage or by some natural phenomenon could not be determined because the dive had to be stopped due to the weather conditions.

\section{Conclusions}

MEDUSA is an instrument that can measure methane and oxygen concentrations in-situ, continuously and on line from natural background up to saturation concentrations. First measurements in the North Sea proved the viability of the system. Various depth profiles have been obtained, and remain open for interpretation. Horizontal profiles across a natural seepage show the distribution around the source. Measurements around a gas injection wellhead may give a hint of a leak in the structure.

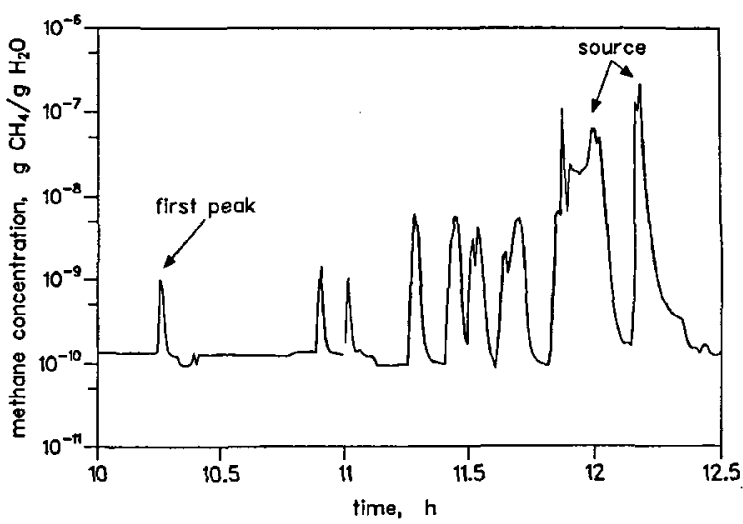

Fig. 12. Result of methane concentration measurements when tracking an enhanced methane concentration from its first appearence to its source.

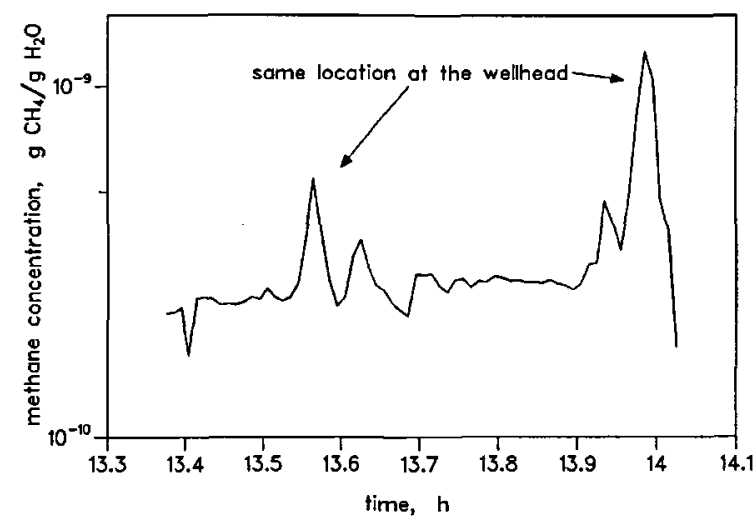

Fig. 13. Methane concentration measurements at the gas injection wellhead $\mathrm{A} 4 \mathrm{H}$ in the Gullfaks area. The maxima at the same location at the wellhead may give a hint of a microleakage.

Bulletin of the Geological Society of Denmark 


\section{Acknowledgement}

This work was sponsored by the Commission of the European Communities. Support by Mr. Hovland from Statoil for giving us coordinates of possible seepages and by Statoil for allowing measurements at their installations is gratefully acknowledged. We also want to thank the staff of Stolt-Comex Seaway A/S and especially the crew of the M/S "Seaway Commander" for the support during the cruise. Without the design and construction work of H.-O. Boie, F.Borchers, S.Motzkau, G.Musielak, J.Burmester, W.Puls and other people from the mechanics and electronics workshop the project would never have been completed.

\section{Dansk sammendrag}

I det foreliggende arbejde beskrives et apparatur til kontinuerlige målinger af opløst methan i havvand. Apparaturet extraherer den opløste methan og bestemmer derefter kvantitativt methanens partialtryk ved hjælp af laser absorption spektrometri. Der er opnået en detektionsgrænse på $30 \mathrm{ppt}$, dvs. $30 \mathrm{pg}$ methan pr. gram vand. Der er således opnået mulighed for at måle den naturlige baggrundskoncentration (ca. $35 \mathrm{ppt}$ ) i oceanisk havvand.

Der er udført målinger i vertikale profiler på to lokaliteter i Nordsøen på den norske kontinentalsokkel ved Statpipe og i Bømla Fjord. Desuden er der udført et horisontalt profil $\mathrm{i}$ forbindelse med et submarint gasudslip nær oliefeltet Gullfaks. Metoden gør det muligt på baggrund af forhøjede methankoncentrationer $i$ vandsøjlen at afsløre tilstedeværelsen af naturlige gasudslip fra havbunden og dermed at kunne efterforske forekomsten nye gas og oliefelter. Desuden vil det være muligt at spore eventuelle lækager i undersøiske gasinstallationer.

\section{References}

Brooks, J. M. \& Sackett, W. M. 1973: Sources, sinks and concentrations of light hydrocarbons in the Gulf of Mexico. J. Geophys. Res. 78, 5248-5258.

Charlou, J. L., Rona, P. \& Bougault, H. 1987: Methane anomalies over TAG hydrothermal field on Mid Atlantic Ridge. J. Mar. Res. 45, 461-472.

Charlou, J. L., Bougault, H., Appriou, P., Jean-Baptiste, P., Etoubleau, J. \& Birolleau, A. 1991: Water column anomalies associated with hydrothermal activity between $11^{\circ} 40^{\prime}$ and $13^{\circ} \mathrm{N}$ on the East Pacific Rise: discrepancies between tracers. Deep-Sea Research 38, 569-596.

Heyer, J. 1990: Der Kreislauf des Methans. Akademie-Verlag Berlin.

Lamontagne, R. A., Swinnerton, J. W., Linnenbom, V. J. \& Smith, W. D. 1973 : Methane concentrations in various marine environments. J. Geophys. Res. 78, 5317-5324.

Schmitt, M., Faber, E., Botz, R. \& Stoffers, P. 1991: Extraction of methane from seawater using ultrasonic vacuum degassing. Anal. Chem. 63, 529-532.

Swinnerton, J. W. \& Linnenbom, V. J. 1967: Determination of the $C_{1}$ to $C_{4}$ hydrocarbons in sea water by gas chromatography. J. Gas Chrom. 5, 570-573.

Wernecke, G., Flöser, G., Korn, S., Michaelis, W. \& Weitkamp, C. 1991: Device for the in-situ determination of methane in sea water. Report GKSS 91/E/44, Forschungszentrum Geesthacht, Geesthacht. 